\title{
EDUCATION FOR THE FUTURE: New Strategies of Distance Education For The Universities of Eastern Siberia
}

\author{
Vladimir I. KIRKO \\ Department of Management Organizations, \\ Krasnoyarsk State Pedagogical University \\ named after Victor Astafijev, RUSSIA
}

Ekaterina V. MALAKHOVA

Krasnoyarsk State Pedagogical University named after Victor Astafijev, RUSSIA

\section{ABSTRACT}

Nikolay I. PACK

Department of Informatics and Information Technologies in Education Krasnoyarsk State Pedagogical University named after Victor Astafijev, RUSSIA

This article discusses the main trends of global education and educational problems in the Arctic and Siberian regions. The modern labor markets are changing in the Arctic. The modern labor market requires the creation of new jobs associated with the provision of the Arctic zone with food. Small food productions will be created. We will need a mobile change of professional competence of those workers who work in the Arctic zone. Global world creates global competition in education. The quality of education and research in the region is the main source of development of this region. Economic and social development of the Arctic zone is impossible without the development of modern universities in the Siberian Arctic. In the near future the number of universities in the area of the Arctic and Siberian Russia will be reduced by 2 times. In this situation a complete transition to distance learning technologies is necessary. Krasnoyarsk State Pedagogical University named after V.P. Astafijev (KSPU) has established a network of Resource Centers in Krasnoyarsk Region (Eastern Siberia, Russia). Distance Education Resource Centers are connected into a single network, with the main center in KSPU (Krasnoyarsk, Russia). The Unified Network of Resource Centers, through distance education, will provide the required professional competence for people of the Arctic and the Northern zones of Eastern Siberia.

Keywords: Arctic, Siberia, distance education, resource center, professional competence 


\section{INTRODUCTION}

The rivalry between states and regions in economic, political and humanitarian fields is expressed explicitly; therefore there are increased demands for their competitiveness. That is why now we should not just reflect on that, but make efforts for the formation of the modern generation of professionals, that will make regional societies competitive in the context of globalization. In the context of globalization and technology development we should have a clear idea of what will happen in the processes of global (worldwide) separation of production and related productive forces. For example, we regard the United States as a leader in the field of software and computers, Japan - as a leader in the automotive industry, China (until recently) - as a country of mass production of consumer goods, Russia - as the state with cosmic rockets and gas etc. Further development of technologies (robotization and computerization) will lead to intensification of the processes of globalization.

As a result of competition between countries, such changes will occur in the global division of labor, when the country with high productivity and low cost of a material (tangible) product will take the leading position, as well as the countries where "...the knowledge and skills are the only source of competitive advantage ... Today it is in the countries where there are the best brains..." -so said the economist from MIT Lester Thurow (Michio Kaku, 2011).

In this regard it should be noted that this fact was first understood in the United States, when President Abraham Lincoln at the height of the civil war between the North and the South signed "the Act of Morrill" in 1882, which granted land to universities as an endowment for their continued survival and development. This law contributed to the development of science and innovation and the creation of a network of research universities (Malkova, 2002).

The current U.S. President Barack Obama confirmed this approach in the crisis of 20082009. "... We will allocate more than 3 percent of GDP for research and development. We will not just reach; we will surpass the level of the times of Space Race by investing in fundamental and applied research, creating new incentives for private innovation, supporting breakthroughs in power engineering and medicine, and improving math and science education. This is the largest investment in research and innovation in American history. The decision to support science, which I take today, will fuel our success for the next 50 years. This is the only way for us to make the work of the present generation the basis for progress and prosperity in the XXI century in the eyes of our children and grandchildren" (Obama, 2009).

"Good brains" are needed to make use of the funds allocated by the U.S. government. The U.S. President switched on the "brain vacuum cleaner" along with facilitating issuing visas and "Green Cards" for scientists (H-1B visa or "visa for geniuses"). For example, in the famous Silicon Valley, about half of the scientists are immigrants, and New York University has almost $\mathbf{1 0 0 \%}$ of graduate students from other countries. 
Instructive is the example of the city-state of Singapore, which in the course of $\mathbf{4 0}$ years of development, from the country's shabby seaport, the city of drug trade, smuggling and recreation area for sailors turned into the modern country, exporting modern high-tech electronics, biomedical equipment and products of chemical production. Together with the introduction of "draconian laws" in criminal law, the former Prime Minister of Singapore Lee Kuan Yew made a real technological and cultural revolution, and a revolution in education, the foundation of which was that creative students were marked at the earliest stages and they developed at their own pace (Lee Kuan Yew, 2010).

\section{WHAT LESSONS IN STRATEGY}

\section{FORMATION OF EDUCATION DOES MODERN SINGAPORE PROVIDE?}

The Education System in Singapore is part of a modern integrated Public System. The state has a clear Strategy and goals of its development. The main strategic directions of the state (the national idea): to become a world leader in the field of oil, in the manufacture of electronic equipment, genetic engineering, marine ecology, based on innovations, technologies of the future and the society of labor and mind. Estimates of income from these industries allow procuring all necessary things for comfortable living of citizens and even expanding the land due to delivery of sand from the ocean and the purchased uninhabited islands.

These revenues allow creating rich society, to create conditions for a happy life. Special personnel policy was developed for the purposes of production, the economy, construction of high-tech infrastructure of the city-state.

The mission formulated for the Ministry of Education is to organize a system that allows preparing the necessary specialists with the necessary qualities. The budget of the country has a fixed safeguarded item of expenditure on education (8-10\%). This mission of education poses specific challenges to educational institutions from kindergarten to postgraduate education. If the leadership of the Ministry of education is unable to cope with its mission, its personnel structure will change. Also there will be a change of heads of any educational institution if they cannot cope with their tasks. The criterion of success of the ministry as a whole and each individual educational institution in particular, are their graduates. In its turn, each level of education has its demands to the previous level of education, which supplied it with students: kindergarten - to parents, school - to kindergartens, colleges and institutes- for high school graduates, and universities- to the institutes. The activities of all levels of education are monitored automatically by analyzing the labor market: what graduates work more successfully in various fields. In this case it is assumed that not less than $30 \%$ of the graduates of the university should be working in the profession of their training.

Thus, in Singapore there is a clear state order for education and criteria for evaluating the quality of educational institutions. However, few people care about the educational process itself inside the educational institution. To prevent the monopoly (in educational market), competitive institutions are set up. 
Therefore each educational institution has its own vision and mission. To solve the problem of the state - to achieve high quality of their "product" -the graduates- the management of education institution applies new methods, approaches, innovations and other advanced technologies of the future for forward-looking training aimed at the success of their students in the future.

\section{MODERN TRENDS IN THE LABOR MARKET \\ IN KRASNOYARSK REGION (EASTERN SIBERIA, RUSSIA)}

With the increased productivity and robotization, there will be a gradual saturation with material (tangible) products, which will lead in some countries to the disappearance of a number of professions.

These changes require a change in educational strategy in modern Russian universities. The purpose of this article is the analysis of strategic lines of development of modern education and the supply of new educational technologies for the future of education. Particular attention will be paid to the situation in the universities of Eastern Siberia (Russia), which should prepare professional personnel for the development of the Arctic and North zones (Koptseva, 2013).

The changes in Russian labor market are linked heavily with agriculture. Employment in agriculture in 2012 amounted to about $23 \%$ of that of 1990 , thus crop area was reduced too- up to 55\% compared to 1990 (Mekhanik, 2014). Due to the rapid growth of ecommerce, a $30 \%$ increase in the number of logistic centers can be predicted in the year 2013 as compared to the year 2012, which will entail a reduction in the number of "conventional" sellers. With the development of distance learning and educational opportunities in the leading educational institutions of the world, competition among universities will apparently intensify and the number of teachers will be reducing. Because of computerization and robotization, a number of working and engineering professions will disappear in the future. For example, in Krasnoyarsk region, despite an increase in oil production of "Vankorneft" by almost 1.5 times compared with 2010 (from 13 million tons to $\mathbf{2 1 . 4}$ million tons), the number of employees has reduced due to the high productivity, that exceeded the national productivity by 10 times (Semykina and Sylkin, 2014).

In connection with the above said, it is necessary to determine the trends of the future and shape them in accordance with the content of education for our younger generation, ranging from kindergarten to universities. We consider the following key trends:

$>$ Globalization of the economy, reducing production costs, material (tangible) product saturation, increasing demand for intellectual products in comparison to material consumption;

$>$ Disappearance of a number of professions in connection with the development of technology of material production; 
$>$ Development of IT- technologies, the Internet;

$>$ Localization of training and educational processes in the best educational institutions of the world;

> Development of economy of experiences and emotions (tourism, arts, entertainment, etc.);

$>$ Ecologically cleaner production and products;

$>$ Solving the problems causing global geological, cosmic and social disasters;

> Development of science and technology (artificial intelligence, robotics, nanotechnology, energy, biotechnology and cognitive science).

$>$ What are the challenges for modern education in Russia, based on these trends:

$>$ What should be taught to be competitive?

Who will teach, how to be a teacher and what should be the teacher's competence in the field of educational technologies of the near future?

$>$ Who should we teach for?

$>$ What educational technologies must be used?

$>$ What should be done with education in Russia at present?

\section{ANSWERS OF SCIENCE FICTION WRITERS AND FUTURISTS}

These questions can be answered by studying the works of the well-known science fiction writers and futurists, who often predicted the great inventions and the future of mankind - from Leonardo da Vinci (15th century) to Raymond Kurzweil, J. Barker and Michio Kaku (21st century) (Kaku 2011).

Leonardo da Vinci (1452-1519) - the first futurist in history, who made the correct prediction about the design of a car, a helicopter, a diving suit, loom, rolling machine, of multi-weapon (gun), etc. - almost 200 years before they were created. H. G. Wells $(1886-1946)-10$ years before Einstein and Minkowski announced that our reality is a four-dimensional space-time (1895-Publication of the book "The Time Machine"). He predicted a future war with the use of poisonous gases, aviation, devices like laser (1898 - first publication of the book "War of the Worlds").

The Russian writer Alexander Belyayev (1882-1942) in his fantastic book "Professor Dowell's Head" predicted transplantation, in his book "Eternal bread" - the future of Biochemistry and Genetics, in his the book "Star KEC" shows the prototype of modern orbital stations. Raymond Kurzweil, American inventor and futurist, in his book "The era of spiritual machines," published in 1998, made 108 predictions for 2009, 98 of which were correct. In R. Kurzweil's predictions for 2019 we distinguish those that may be related to technologies of education:

$>$ A special device will project an image inside the human eye, creating an augmented reality ( already have prototypes);

$>$ Continuous ubiquitous wireless broadband Internet; 
$>$ Computers will lead to the almost complete disappearance of paper documents and books;

$>$ Training will occur through training programs with simulated interactive teachers. Students will learn remotely;

$>$ People will spend most of their time on acquisition of knowledge;

$>$ Virtual artists and musicians in arts will be wide spread (Kurzweil, 2005).

Joel Barker writes about learning technologies in the future: "Consider education. You are immersed in virtual reality and you start exploring atoms with your chemistry teacher. You see the electron cloud. If you specify the object which you want to approach ... the computer will register your gesture and generate the image..." (at the international exhibitions of IT-technologies the models of similar devices were already demonstrated) (2007). Given the current trend of globalization and the rapid development of IT-technologies, according to a German professor Erwin Haeberle, "...the expansion of university education will take place on the Internet, which will lead to a total change in the scientific world" (Haeberle, 2013). In connection with the trend of globalization, is it possible to predict the future of certain professions on the example of such an important region of the world as Siberia? We will do this on the example of Eastern Siberia, Krasnoyarsk Region.

\section{FUTURE LABOR MARKET IN EASTERN SIBERIA (ON THE EXAMPLE OF KRASNOYARSK TERRITORY)}

Localization of material production in regions and countries with high productivity and low cost of production, and Russia's entry into the World Trade Organization will lead to the fact that in agriculture only automated complexes of complete production cycle will remain competitive, competing with complexes of Altai, Krasnodar Territory (regions of Southern Russia and Southern Siberia). Global competitiveness of Krasnoyarsk Territory in this area can be provided with production of food of high ecological purity that requires large investments into product certification. Besides that, in connection with the remoteness and transport inaccessibility of villages of the Far North and the Arctic, new local mini productions, providing these Northern and Arctic settlements with basic food (bakery products, dairy products, preserving and processing the products of hunting, fishing, etc.) can be quite competitive, as well as the production of products with high added value, such as a mini- production for processing of deer antlers in the village of "Surinda" of Evenk Municipal District based on the technology of Victor Nevzorov, professor of Krasnoyarsk State Agricultural University (Nevzorov and Kozhukhar, 2013). Taking into consideration the competitive potential of the territory, climatic conditions and its remoteness and transport inaccessibility, it seems that the number of individually trained specialists, that will be necessary in the agro-industrial complex in Krasnoyarsk Region in the future, will be limited. There will be demand for specialists who are familiar with the national traditions of the indigenous peoples of the North, engaged in traditional economic activities (Reznikova, 2013; Pimenova, 2014, Palchin, 2013, Krivonogov, 2013). 
On the one hand, due to automation and robotization, we can expect a constant decline in working and engineering professions. On the other hand, the demand for programmers as well as specialists in the field of robotic technology will continue to grow. We can hardly expect the increase in the demand for specialists in such areas as oil exploration, oil and gas production, oil refining, metallurgy, etc., as these sectors have become transnational and can "pick" technology and specialists (for example, corporation "RUSAL") from all over the world. Training of such specialists requires an individual approach to their education.

In connection with the transformation of society from the society of material production into intellectual society (society of experiences, art, science) there will increase the demand for the specialists possessing creative abilities. Preservation of cultural, ethnic and religious tolerance requires specialists in the field of culture, religion, psychology, etc.

With the development of IT- technology, high-speed Internet and the globalization of the world of education, it will radically change its system and form, which will require changes in the requirements for professional competence and skills of lecturers and teachers in schools. Alongside with traditional methods it will be necessary to adopt new pedagogical technologies.

The modern task of educational institutions is to help the students master the universal types of activity, which can be applied in the educational process as well as in real-life situations, in which the necessary competences will be formed.

The Agency for Strategic Initiatives of the Russian Federation in the book "Atlas of New Professions" provided a list of future occupations and competencies, that it will be necessary to introduce in the near future for the education of professionals:

$>$ a moderator - a specialist in the organization of collective creative work of students;

$>$ a developer of educational trajectories in terms of the individual approach - for the formation of educational programs according to the abilities and interests of the student;

$>$ a tutor-teacher, who helps to learn educational programs using modern IT- technology, telecommunications, virtual simulators, etc.;

$>$ an organizer of project-based learning - a specialist in the formation and implementation of real projects from the economy or the social sphere;

$>$ an educational coordinator of an on-line platform - a specialist, providing, based on the individual student's educational trajectory, on-line access to global educational resources.

Besides that there also will be needed specialists in the sphere of computer animation, developers and managers of educational programs in 3D. The teachers will need to have competence of the production directors of virtual reality. 
The question of formation of generic competences of the "new generation" is also important. What universal abilities should a person in the society of future have to "stay afloat", to be successful? What is it necessary to fill the content of the proposed professions with?

What competencies are the basis of a person's success in the society of the future, his personal realization, development, active citizenship, social inclusion and employment? The Recommendation of the European Parliament and of the Council of 18 December 2006 "On the key competences for lifelong learning for citizens in a society based on knowledge" considers eight main core competencies as necessary:

$>$ The ability to communicate in one's native language;

$>$ The ability to communicate in foreign languages;

$>$ Math competence and basic competences in science and technology;

$>$ Digital competence;

$>$ Ability to learn;

$>$ Social and civic competence;

$>$ Ability to initiative and entrepreneurship;

$>$ Cultural competence.

\section{NETWORK OF RESOURCE CENTERS IN THE TERRITORY OF EASTERN SIBERIA AND THE SIBERIAN ARCTIC}

In this regard, the creation of effective methods of distance education using on-line telecommunications broadcast is important. Training of educational personnel of the future for remote and difficult of access areas and in the conditions of limited access to high-speed Internet connection, can be started using the experience of Krasnoyarsk State Pedagogical University named after Victor Astafiev, which has created its own network of resource centers in different districts of Krasnoyarsk Region (including the North and the Arctic), which may serve as multipurpose centers providing applied qualifications, where training and retraining of specialists will take place. The modern paradigm of education in global information and communications is associated with the e-learning, artificial intelligence, cloud technologies.

They are targeting the development of cognitive abilities, self-knowledge and production of high technology, innovation and information services. The area of artificial intelligence has now gained new momentum. The experts do not link artificial intelligence with downloading the human mind as a computer program. The computer will control the "normal" human mind. It will be an integration of the human body with artificial intelligence and the human mind with artificial human body (as a set of artificial organs). Networking Internet infrastructure will allow creating a cloud of mind - "The HyperBrain", which will be linked to each person. The team of the Department of Informatics and Information Technologies in Education of the Krasnoyarsk State Pedagogical University named after Victor Astafijev designed and formed the methodological model of "Hyper-brain" for upgrading teacher education. 
The project aims at developing and implementing a regional model training of a new generation of teachers and their continuing professional development through the creation and implementation of an integrated model of education cluster training of pupils and students of pedagogical high school in horizontal and vertical mega-classes with the use in real educational process education by mind cloud (including schools, universities, IT-companies, academic institutions).

This project is able to provide these positions:

$>$ increasing interest in training students in the school and students in high school, teachers to the profession through creative module containing living tasks and situations, to exercise and to use satellite sensing, astronomical observations, robotics projects, environmental development activities in the IT-industry, artificial intelligence to participate in the development of "The Smart Internet", "The Smart Planet", "The Smart City", "The Smart Home" and so forth;

$>$ comfortable network of on-line and of-line communication by communicative module containing network services for exchange of text, audio, video information to all participants in the educational process, with filters access to useful social networks;

$>$ cognitive development of students and teachers at the expense of mental module that contains the methods and techniques of computer psychological diagnosis, psychological didactics, mental didactics, methods of development of memory, attention, and algorithmic logic (sequential and parallel) thinking;

$>$ forming of the basic integrated thesaurus through educational module containing intelligent training systems for self-educational activity of students;

$>$ development of research and design style of thinking through research module containing the necessary resources and materials, including virtual environments and laboratories for research students, students and scientists within the vertical cluster of mega-groups;

$>$ management and administration of scientific and educational process of mega-cluster complexes by management of module containing electronic journals, individual portfolio, electronic document management and reporting;

$>$ conditions for training of pupils and students on technology megalessons, mathematics, physics and chemistry, as well as integrated course all of these disciplines through methodical module containing the open cluster system projective methodical training Mega-classes on the horizontal axis, intergenerational teaching and research activity on the vertical axis (curricula, programs, courses, methodological and software support, etc.). 


\section{CONCLUSION}

The climate and landscape of the Arctic Siberia pose special challenges for distance education in Russia. The Krasnoyarsk Pedagogical University named after Victor Astafijev is doing two projects in the field of distance education. These projects are designed for people who live in remote areas of the Arctic Siberia. The first project is the creation of a network of centers for distance education at Krasnoyarsk Pedagogical University named after Victor Astafijev.

The second project -- is the creation of a model "The Hyper Brain" and the creation of "Mega-Class", "Mega-Lessons" that involve modern information systems, which include professors, teachers, students, and pupils of Eastern Siberia.

The modern distance education can solve the problem of labor market conditions in the global competition for educational services in a constantly changing demand for skills and professional competence.

\section{BIODATA and CONTACT ADDRESSES of the AUTHORS}

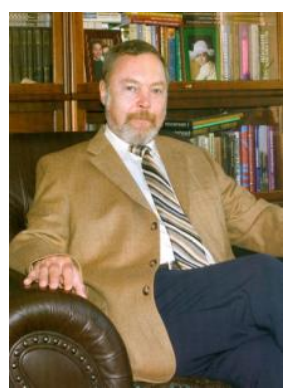

Vladimir I. KIRKO

Department of Management Organizations, Krasnoyarsk State Pedagogical University named after Victor Astafijev, 89 Ada Lebedeva St., Krasnoyarsk, 660049, RUSSIA

Phone: +79620824716

Fax: +73912171717

Mobile: $\mathbf{+ 7 9 0 8 2 1 1 4 1 2 3}$

Email: director.nifti@mail.ru

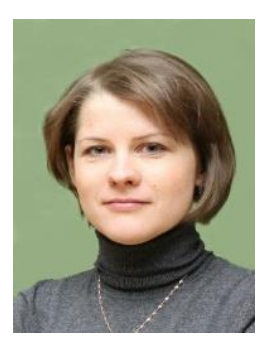

Ekaterina V. MALAKHOVA, Laboratory of Problems formation of character of the current generation of Siberians, Krasnoyarsk State Pedagogical University named after Victor Astafijev, 89 Ada Lebedeva St., Krasnoyarsk, 660049i RUSSIA

Phone: +79620824716

Email: malahovaev@mail.kspu.ru

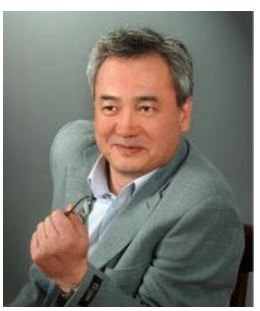

Nikolay I. PACK

Department of Informatics and Information Technologies in Education, Krasnoyarsk State Pedagogical University named after Victor Astafijev, 89 Ada Lebedeva St., Krasnoyarsk, 660049, RUSSIA

Phone: +79620824716

Email: nik@kspu.ru 


\section{REFERENCES}

Barker, J. (2007). The Power of Paradigms. Moscow. Publisher Alpina Business Books.

Haeberle, E. (2014). There will be only 10 universities. Expert, 48 (878), 23-27.

Kaku, M. (2011). Physics of the Future, New York: Doubleday; First Edition, 2011, 416 p.

Krivinogov, V. P. (2013). The Dolgans' Ethnic Identity and Language Processes. Journal of Siberian Federal University. Humanities \& Social Sciences, 6, (6), 870-881.

Koptseva, N (2013). The Results of Theoretical and Experimental Research of the Modern Problems of the Indigenous Small-Numbered Peoples of the North, Siberia and the Far East in Siberian Federal University. Journal of Siberian Federal University. Humanities \& Social Sciences, 5, (6), 762-772.

Kurzweil, R. (2005). The Singularity is Near: When Humans Transcend Biology. New York:

Lee, Kuan Yew (2010) The Singapore Story. 1965-2000. From the Third World - in the First. Moscow: Publishing House "MGIMO-University".

Malkova, Z. (2002). Pedagogical features of the organization of scientific research in the United States. Pedagogy, 6, 89-95.

Mechanic, A. (2014). Should Russia become a desert? Expert, 4 (883), 34-38.

Nevzorov, V., \& Kozhukhar, E. (2013). Improving the design of devices for grinding nonwood plant materials based on patent research.

http://www.kgau.ru/new/all/konferenc/konferenc/2013/f6.pdf 21.01.2013.

Obama B.(2009). Remarks by the President at the National Academy of Sciences Annual Meeting. The White House. Office of the Press Secretary. April 27, 2009.

Palchin, S. (2013). The Current Social and Economic Data on the Indigenous Small-Numbered Peoples of the North as of 2012. Journal of Siberian Federal University. Humanities \& Social Sciences, 6 (6), 913-924.

Pimenova, N. (2014). Cultural heritage of indigenous peoples of the Krasnoyarsk Territory and modern cultural practices. NB: The Cultures and Arts, 2, 28-66.

Reznikova, K. (2013). Preservation and Transformation of Certain Aspects of the Traditional Way of Life of the Indigenous and Small-Numbered Peoples of the North, Living in the Settlements (Posyolki) of Turukhansk and Farkovo. Journal of Siberian Federal University. Humanities \& Social Sciences, 6, (6), 925-939.

Semykina, I., \& Silkin, B. (2014) We have what we can do. Expert Siberia, 9 (408), 26-27. 